\title{
MODEL SIMULASI PRAKIRAAN CH BULANAN PADA WILAYAH RIAU DENGAN MENGGUNAKAN INPUT DATA SOI, SST, NINO 3.4, DAN IOD
}

\author{
Aristya Ardhitama *, Rias Sholihah ${ }^{2 *}$ \\ 1) PMG Muda Stasiun Meteorologi Pekanbaru, 2) Mahasiswi Geofisika dan Meteorologi-FMIPA-IPB \\ ardhi.tama@gmail.com, riassholihah.sb94@gmail.com
}

\begin{abstract}
INTISARI
Saat ini, kondisi cuaca di Pekanbaru dewasa ini begitu cepat perubahannya sehingga sulit diprediksi. Fenomena ini menuntut prakiraan untuk meningkatkan kualitas hasil prakiraan sehingga lebih cepat, tepat, dan akurat untuk hasil yang diinginkan tersebut. Simulasi prakiraan jumlah curah hujan dengan menggunakan input data prediktor SOI, SST, Nino 3.4 dan IOD dengan parameter cuaca di Kota Pekanbaru telah dilakukan menggunakan model persamaan regresi linear berganda. Prediktor tersebut digunakan untuk memprediksi curah hujan (CH) tahun 2011 dan 2012.Selain itu berfungsi untuk mengecek kebenaran hasil prakiraan jumlah curah hujan dengan model persamaan regresi linear berganda menggunakan rumus Root Mean Square Error (RMSE) dan Standar Deviasi (SD).Serta kajian penelitian ini berfungsi untuk membuktikan faktor prediktor (SOI, SST, Nina 3.4 dan IOD) yang paling mempengaruhi kondisi curah hujan di Pekanbaru.Data yang digunakan dalam kajian ini adalah data curah hujan sebaran normal dari tahun 1981-2010 pada stasiun wilayah Pekanbaru-Provinsi Riau. Data jumlah curah hujan tahun 2011 dan 2012 hasil observasi dianggap sebagai pembanding untuk verifikasi dan validasi nilai curah hujan ( $\mathrm{CH}$ ) hasil model output simulasi.Berdasarkan penelitian yang telah dilakukan maka dapat disimpulkan bahwa data dari SOI, SST, Nino 3.4 dan IOD memiliki pengaruh terhadap curah hujan di wilayah Pekanbaru Provinsi Riau.Kondisi cuaca terutama curah hujan untuk wilayah Pekanbaru dipengaruhi oleh factor global, regional dan lokal.Dari hasil penelitian terlihat hubungan yang memiliki tingkat korelasi yang tinggi terhadap curah hujan $(\mathrm{CH})$ adalah prediktor SOI.Selain itu, dengan menggunakan RMSE membuktikan bahwa nilai kebenaran pada tahun 2011 lebih baik dibandingkan pada tahun 2012.
\end{abstract}

Kata Kunci: Cuaca, Curah hujan, SOI, SST, Nino 3.4 dan IOD, Validasi

\section{PENDAHULUAN}

Kondisi cuaca di Pekanbaru dewasa ini begitu cepat perubahannya sehingga sulit diprediksi. Fenomena ini menuntut prakiraan untuk meningkatkan kualitas hasil prakiraan sehingga lebih cepat, tepat, dan akurat untuk hasil yang diinginkan tersebut, maka dibuatlah prakiraan jangka pendek yang berlaku setiap pergantian hari (prakiraan cuaca). Pergantian musim di Indonesia sangat dipengaruhi oleh aktivitas monsun, namun sifat musim tidak selalu sama dengan normalnya. Kadang-kadang dapat ditemui periode dengan curah hujan umumnya di atas normal, Dan juga ditemui suatu periode dimana curah hujan umumnya di bawah normal. Hal tersebut menunjukkan bahwa selain monsun, masih terdapat faktor-faktor lainnya yang berperan dalam pembentukan musim di Indonesia seperti fenomena global yang disebut dengan el nino dan la nina ${ }^{[12]}$.

Musim di Indonesia selain dipengaruhi oleh Monsun dan pengaruh lokal, juga dipengaruhi oleh adanya fenomena global, diantaranya sirkulasi Hadley, sirkulasi Walker, El Nino, La Nina, Indian Ocean Dipole Modedan pola lokal setempat. Variasi cuaca dan iklim sangatlah perlu diperhatikan karena sebagian wilayah Indonesia terletak di Belahan Bumi Utara dan sebagian di Belahan Bumi Selatan. Meskipun musim hujan dan kemarau terjadi secara periodik, tetapi panjang musim dan jumlah curah hujan untuk setiap musim tidaklah selalu sama. Kondisi ini menunjukkan bahwa musim di wilayah Indonesia tidak hanya dibentuk oleh monsun, tapi dibentuk juga oleh faktor lain yang berinteraksi dengan monsun untuk membentuk musim tersebut ${ }^{[15]}$. 
Provinsi Riau beriklim tropis basah dengan rata rata curah hujan berkisar antara 1000-3000 $\mathrm{mm}$ per tahun yang dipengaruhi oleh musim kemarau dan musim hujan. Daerah yang paling sering ditimpa hujan setiap tahun adalah Kota Pekanbaru 193 hari, Kabupaten Indragiri Hulu 178 hari, Kabupaten Pelalawan 147 hari, Kabupaten Rokan Hulu 136 hari, dan Kabupaten Kampar denganjumlah hari hujan 110 hari. Jumlah Curah Hujan tertinggi pada tahun 2009 terjadi di Kabupaten Kampar dengan curah hujan sebesar $3.349 \mathrm{~mm}$, disusul Kota Pekanbaru sebesar $3.214,4 \mathrm{~mm}$, sedangkan curah hujan terendah terjadi di Kota Dumai sebesar 635,0 mm. Selanjutnya menurut catatan Stasiun Meteorologi Simpang Tiga, suhu udara rata rata di Kota Pekanbaru tahun 2009 menunjukkan $28^{\circ}$ celcius dengan suhu maksimum 36,0 celcius dan suhu minimum $21^{\circ}$ celcius.

Propinsi Riau merupakan jalur ekuator sehingga membentuk pola curah hujan ekuatorial. Pola hujan ekuatorial memiliki dua puncak hujan yang terjadi saat matahari berada dekat ekuator, yaitu sekitar bulan Maret dan Oktober ${ }^{[19]}$.

Pola ekuatorial dibagi menjadi tipe $D$ dan tipe E. Tipe $D$ mencakup wilayah pantai barat Sumatera Utara, sedangkan tipe E mencakup daerah wilayah pantai barat Sumatera Selatan. Pada wilayah ini musim kemarau tidak begitu jelas [6].

Memprakirakan cuaca adalah satu pekerjaan yang tidak mudah, karena cuaca itu sendiri merupakan fungsi ruang dan waktu yang artinya cuaca sangat bergantung pada tempat (ruang), dan waktu. Di samping itu, prakirawan dituntut harus memahami sifat-sifat atmosfer dan dinamika atmosfer serta diperlukan pengalaman dan keberanian dalam membuat suatu keputusan prakiraan.

Memahami dan mempelajari fenomena cuaca dari waktu ke waktu tersebut merupakan modal yang sangat penting untuk dapat memprakirakan cuaca di waktu yang akan datang. Kejadian hari ini tidak terlepas dari kejadian yang terjadi kemarin dan kejadian esok hari tidak akan terlepas dari kejadian hari ini. Prakiraan cuaca akan berhasil baik dan benar (akurat) jika prakirawan memiliki kemampuan yang memadai, memiliki sarana dan prasarana serta lengkap sehingga dapat menghasilkan data yang diperlukan dengan kualitas yang baik yang dapat mempertajam analisa. Dari uraian di atas penulis ingin meneliti tentang faktor fisis cuaca yang mempengaruhi curah hujan.Dalam kajian penelitian ini penulis ingin membuktikan bahwa adanya hubungan curah hujan dengan menggunakan data SOI, SST, Nina 3.4 dan IOD

\section{TINJAUAN TEORI}

\subsection{Pengertian Dasar tentang Cuaca dan Iklim}

Ada beberapa pengertian yang berkaitan dengan cuaca, menurut ${ }^{[20]}$, cuaca adalah keadaan variabel atmosfer secara keseluruhan disuatu tempat dalam selang waktu yang pendek. Sedangkan menurut ${ }^{[8]}$, cuaca adalah keadaan atmosfer yang dinyatakan dengan nilai berbagai parameter, antara lain suhu, tekanan, angin, kelembaban, dan berbagai fenomena hujan, disuatu tempat atau wilayah selama kurun waktu yang pendek.

Selain faktor cuaca ada hal lain yang berkaitan dengan cuaca yang disebut dengan iklim. Iklim memiliki pengertian yaitu konsep abstrak yang menyatakan kebiasaan cuaca dan unsur-unsur atmosfer disuatu daerah selama kurun waktu yang panjang ${ }^{[20]}$. Sedang menurut ${ }^{[8]}$, iklim adalah peluang ststistik berbagai keadaan atmosfer, antara lain suhu, tekanan, angin, kelembaban, yang terjadi pada suatu daerah selama kurun waktu yang panjang.

Selain itu ada juga pengertian musim yaitu rentang waktu yang mengandung fenomena (nilai sesuatu unsur cuaca) yang dominan atau mencolok (Kamus Besar Bahasa Indonesia). Sebagai contoh : musim dingin adalah rentang waktu yang selama itu suhu udara selalu rendah, musim hujan adalah rentang waktu yang memiliki banyak terjadi hujan.

Dari beberapa definisi tadi dapat disimpulkan bahwa cuaca adalah keadaan fisik atmosfer pada suatu saat (waktu tertentu) di suatu tempat, yang dalam waktu singkat (pendek) berubah keadaannya, seperti panasnya, kelembabannya, atau gerak udaranya sedang iklim adalah peluang statistik keadaan cuaca rata-rata atau keadaan cuaca jangka panjang pada suatu daerah, meliputi kurun waktu beberapa bulan atau beberapa tahun. Ada beberapa unsur yang membentuk cuaca, yaitusuhu udara, kecepatan angin, angin, tekanan udara, kelembaban udara dancurah hujan ${ }^{[1]}$.

\subsection{CURAH HUJAN}

Hujan adalah mata rantai dari siklus air dan merupakan fenomena di udara yang tergantung pada unsur-unsur cuaca yang lainnya. Hujan memiliki peranan dalam penentuan iklim. Menurut keadaan sebenarnya, hujan di suatu tempat dalam kurun waktu tertentu tidak mempunyai jumlah yang sama sehingga dapat dilihat adanya jumlah curah hujan minimum dan maksimum yang silih berganti secara tidak teratur. Oleh karena itu dapat dikatakan bahwa hujan sebagai objek ilmu cuaca bersama-sama unsur cuaca lain adalah suatu fenomena yang merupakan fungsi dari ruang dan waktu. Dengan kata lain hujan mempunyai distribusi yang bervariasi dengan bentuk penyebaran tertentu menurut tempat dan waktu ${ }^{[18]}$

Adapun pola distribusi hujan tersebut adalah : 
1) Pola hujan ekuatorial, pola ini dicirikan oleh dua kali pencapaian nilai maksimum curah hujan bulanan dalam setahun. Jumlah hujan maksimum terjadi setelah ekinoks. Ekinoks adalah kedudukan matahari tepat di atas ekuator terjadi pada 21 Maret dan 23 September.

2) Pola hujan monsunal, merupakan pola hujan yang memiliki distribusi berbentuk huruf "U" atau "V". jumlah hujan. Pola curah hujan ini dicirikan oleh adanya perbedaan yang jelas antara periode musim kemarau dan musim hujan dalam setahun.

3) Pola hujan lokal, pola curah hujan bulanan ini sangat dipengaruhi oleh keadaan dan kondisi setempat. Faktor pembentuknya secara umum dapat dibedakan dalam dua ragam yaitu naiknya udara lembab secara paksa dari aliran udara yang menuju ke dataran tinggi atau pegunungan dan pemanasan lokal yang tidak seimbang ${ }^{[4]}$.

Sifat hujan terbagi atas tiga kategori :

1) Hujan Normal adalah jika nilai curah hujan antara $85 \%-115 \%$ dari normalnya.

2) Hujan Dibawah Normal adalah jika nilai curah hujan dibawah $85 \%$ dari normalnya.

3) Hujan Diatas Normal adalah jika nilai curah hujan diatas $115 \%$ dari nilai normalnya.

Sedangkan jenis hujan ada tiga yaitu :

1) Hujan konvektif, adalah akibat dari pemanasan dari radiasi matahari, udara permukaan akan mamuai dan naik ke atas, kemudian udara yang naik akan mengembun. Gerakan vertikal udara lembab yang mengalami pendinginan dengan cepat akan menghasilkan hujan deras.

2) Hujan orografik adalah jika pergerakan udara melalui pegunungan atau bukit yang tinggi, maka udara akan di paksa naik. Setelah terjadi kondensasi, tumbuh awan pada lereng di atas angin (windward side) dan hujannya disebut hujan orografik, sedangkan pada lereng di bawah angin (leeward side) udara yang turun akan mengalami pemanasan dengan sifat kering, dan daerah ini disebut daerah bayangan hujan.

3) Hujan konvergensi dan frontal adalah jika ada konvergensi pada arus udara horizontal dari masa udara yang besar dan tebal, maka akan terjadi gerakan ke atas. Kenaikan udara di daerah konvergensi dapat menyebabkan pertumbuhan awan dan hujan. Jika massa dua udara yang konvergen horizontal mempunyai suhu dan masa jenis berbeda, maka massa udara yang lebih panas akan dipaksa naik di atas massa udara yang dingin. Bidang batas antara kedua massa udara yang berbeda sifat fisisnya disebut front $t^{19]}$.

Hujan sangat dipengaruhi oleh iklim dan keadaan topografi daerah,sehingga keadaanya sangat berbeda untuk masing -masing daerah .

\subsection{Nino 3.4}

El Nino-Southern Oscillation (ENSO) merupakan fenomena yang mempengaruhi aktivitas hidroklimat global (Ropelewski dan Halpert, 1986; Kayano, 2003; Chiew et al., 1998; Shrestha dan Kostaschuk, 2005) di antaranya adalah curah hujan (Mc Gregor dan Nieuwolt, 1998), temperatur (Ropelewski dan Halpert, 1987) dan evaporasi. ENSO merupakan fenomena yang terdiri atas dua fase yaitu fase panas (El Nino) serta fase dingin (La Nina); adapun Southern Oscillation (SO) merupakan jungkat-jungkit perbedaan tekanan atmosfer antara AustraliaIndonesia dengan Samudera Pasifik bagian Timur ${ }^{[17]}$. Curah hujan di Indonesia juga dipengaruhi oleh aktivitas ENSO karena terletak pada Inter-Tropical Convergence Zone (ITCZ). Pengaruh ENSO berbeda-beda antarwilayah bergantung pada lokasi dan topografi (Qian et al., 2010) . Wilayah beriklim monsun di Indonesia merupakan wilayah yang terkena dampak ENSO terbesar karena terkait dengan sirkulasi angin di belahan bumi Utara (Asia) dan angin dari belahan bumi Selatan (Australia).

El nino merupakan fenomena global dari sistem interaksi laut dan atmosfer yang ditandai dengan memanasnya suhu permukaan laut di Pasifik Ekuator (Equatorial Pasific) atau anomali suhu permukaan laut di wilayah perairan tersebut positif atau lebih tinggi dari rata-rata suhu permukaan laut yang seharusnya. Sedangkan la nina merupakan kebalikan dari el nino yaitu ditandai dengan mendinginnya suhu permukaan laut di Pasifik Ekuator atau anomali suhu permukaan laut di wilayah perairan tersebut negatif atau lebih rendah dari rata-rata suhu permukaan laut yang seharusnya. Berdasarkan intensitasnya, el nino dapat dikategorikan sebagai berikut ${ }^{[4]}$ :

a) El nino lemah (Weak El Nino) yaitu jika anomali suhu permukaan laut di Pasifik Ekuator bernilai positif antara $\left(+0,5^{\circ} \mathrm{C}\right)$ sampai dengan $\left(+1,0^{\circ} \mathrm{C}\right)$ dan berlangsung selama 3 bulan berturut-turut atau lebih.

b) El nino sedang (Moderate El Nino) yaitu jika anomali suhu permukaan laut di Pasifik Ekuator bernilai positif antara $\left(+1,1^{\circ} \mathrm{C}\right)$ sampai dengan $\left(+1,5^{\circ} \mathrm{C}\right)$ dan berlangsung selama 3 bulan berturut-turut atau lebih.

c) El nino kuat (Strong El Nino) yaitu jika anomali suhu permukaan laut di Pasifik Ekuator bernilai positif antara $>1,5^{\circ} \mathrm{C}$ dan berlangsung selama 3 bulan berturut-turut atau lebih.

Fenomena el nino umumnya berdampak terhadap curah hujan di sebagian wilayah Indonesia akan berkurang. Berkurangnya curah hujan tersebut sangat tergantung dari intensitas el nino yang sedang berlangsung. Mengingat

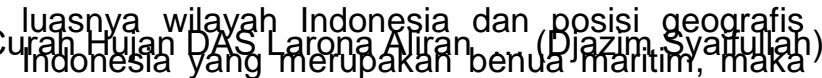
tidak seluruh wilayah Indonesia dipengaruhi oleh 
el nino.Sebaliknya, fenomena la nina umumnya akan berdampak meningkatnya curah hujan di Indonesia yang pengaruhnya juga tergantung dari intensitas la nina yang sedang berlangsung. Gambar 2.1. pada halaman 4 menunjukkan titik pengukuran untuk memperoleh nilai Oceanic Nino Index (ONI) yang terletak di wilayah Samudera Pasifik pada $120^{\circ} \mathrm{BB}-170^{\circ} \mathrm{BB}$ dan $5^{\circ} \mathrm{LU}-5^{\circ}$ LS $^{[4]}$ :

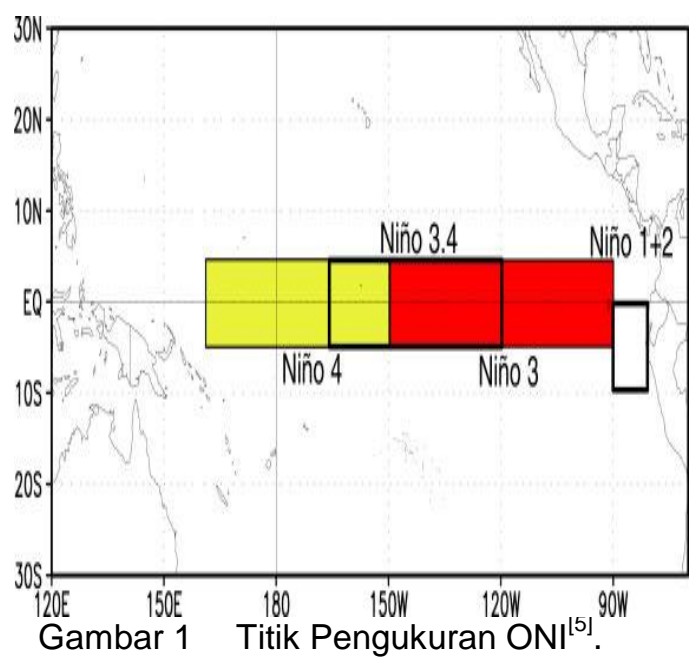

ENSO merupakan fenomena yang terdiri atas dua fase yaitu fase panas (EI Nino) serta fase dingin (La Nina). Southern Oscillation merupakan perubahan sirkulasi angin yang disebabkan oleh perbedaan suhu permukaan laut antara Samudera Pasifik Timur dan Barat (McGregor dan Nieuwolt, 1998; Tjasyono, 2008). Adanya perbedaan tersebut menyebabkan pembalikan sirkulasi atmosfer di atas samudera-samudera/laut yang terletak dekat ekuator (Shelton, 2009). Selama El Nino berlangsung maka temperatur permukaan laut di Samudera Pasifik berubah menjadi lebih panas. Sebaliknya, temperatur permukaan laut di atas Samudera Pasifik menjadi lebih dingin ketika La Nina. Kedua fenomena tersebut terjadi sebagai akibat dari sistem sirkulasi angin, pergerakan atmosfer di atas lautan dan tekanan permukaan di atas laut sepanjang lautan di zona ekuator (McGregor dan Nieuwolt, 1998; NOAA, no date; WMO, 2010).

Fenomena ENSO terjadi ketika suhu udara di Samudera Pasifik meningkat sehingga arah angin berubah. El Nino menyebabkan pergerakan awan mengarah ke timur sehingga curah hujan di Amerika Selatan meningkat. Pergerakan awan mengarah ke barat ketika La Nina sehingga curah hujan di Amerika Selatan meningkat, sebaliknya Indonesia, Australia dan Papua Nugini menerima hujan lebih banyak. Wilayah sebelah barat Samudera Pasifik seperti Indonesia dan Australia mengalami kekeringan, sedangkan di Amerika Selatan terjadi banjir saat El Nino (NOAA, no date).
Indikator untuk menentukan terjadinya $\mathrm{El}$ Nino maupun La Nina adalah SST (Sea Surface Temperature), SOI ((Southern Oscillation Index) dan MEI (Multivariate ENSO Index). Indikator MEI merupakan indikator gabungan antara SOI dan SST sehingga menghasilkan klasifikasi waktu ENSO yang relevan untuk berbagai tempat di dunia. Suatu tahun dinyatakan terjadi El Nino ( $\mathrm{La}$ Nina) apabila nilai MEI $>0,5(<0,5)$ untuk 5 bulan berturut-turut atau lebih antara April tahun (0) sampai Maret tahun berikutnya $(+)$ serta puncak MEI $>1 \quad(<-1)$. Indikator MEI jarang digunakan untuk analisis terjadinya ENSO di Indonesia, biasanya menggunakan SST Nino 3.4. Tahun ENSO menurut indikator Nino 3.4

Adalah tahun El Nino (La Nina) adalah tahun dengan nilai tertinggi $>1+$ standar deviasi $(<$ 1-standar deviasi) (Kiem dan Franks, 2001). Tabel 1.1 menunjukkantahun-tahun kejadian ENSO berdasarkan indikator MEI dan SST Nino 3.4 antara $1970-2010$

\subsection{SOI atau Indeks Osilasi Selatan}

Seorang ilmuan Inggris, Sir Gilbert Walker, pada tahun 1904 tiba di India dengan maksud mencari metode untuk memperkirakan fluktuasi monsun, kemudian dia mencari titik-titik peramalan pada kawasan samudera India dan Pasifik. Melalui berbagai perilaku parameter atmosfer, Walker menemukan suatu gelombang tekanan udara berperioda panjang antara kawasan IndiaAustralia dengan kawasan Amerika Selatan. Adapun titik pengukurun untuk mendapatkan nilai IOS seperti ditunjukkan dalam gambar 2.2. pada halaman delapan sebelah ini. Karena mempunyai gerak berosilasi, maka gelombang tekanan udara tersebut dinamakan sebagai Southern Oscillation. Untuk menghormati penemuannya maka osilasi tersebut dinamakan sebagai Osilasi Walker. Osilasi tersebut telah dibuktikan keberadaannya oleh Berlage (1957) dengan cara mencari penyimpangan tekanan udara tahunan dari berbagai tempat di bumi terhadap tekanan udara di Jakarta (Tjasyono, 2002).

Untuk memantau keberadaan Osilasi Selatan ini dicari harga index dari selisih tekanan udara permukaan Tahiti, sebagai wakil dari kawasan Amerika Selatan, dengan Darwin sebagai wakil dari kawasan India-Australia. Setelah dinormalisasikan, indeks ini diplot dari waktu ke waktu, maka terlihatlah wujud Osilasi Selatan itu. Bila harga indeks negatif, berarti tekanan di kawasan Amerika Selatan lebih rendah daripada kawasan India-Australia, dan demikian pula sebaliknya. Dari osilasi ini bisa di baca ada dua sel tekanan udara, yaitu tinggi dan rendah yang saling berkejaran mengelilingi khatulistiwa bumi. Sedangkan untuk memantau El-Nino digunakan indeks El-Nino yang di plot bersamaan dengan SOI dan didapat hubungan antara keduanya, yaitu jika indeks El-Nino positif, maka 
SOI negatif, dan demikian pula sebaliknya. Jika periode el nino bertepatan dengan turunnya nilai IOS maka periode tersebut disebut dengan ENSO (el nino southern oscillation) (Sribimawati, et al. 1997). Adapun rumus untuk menentukan SOI adalah (Critchfield, 1979) :

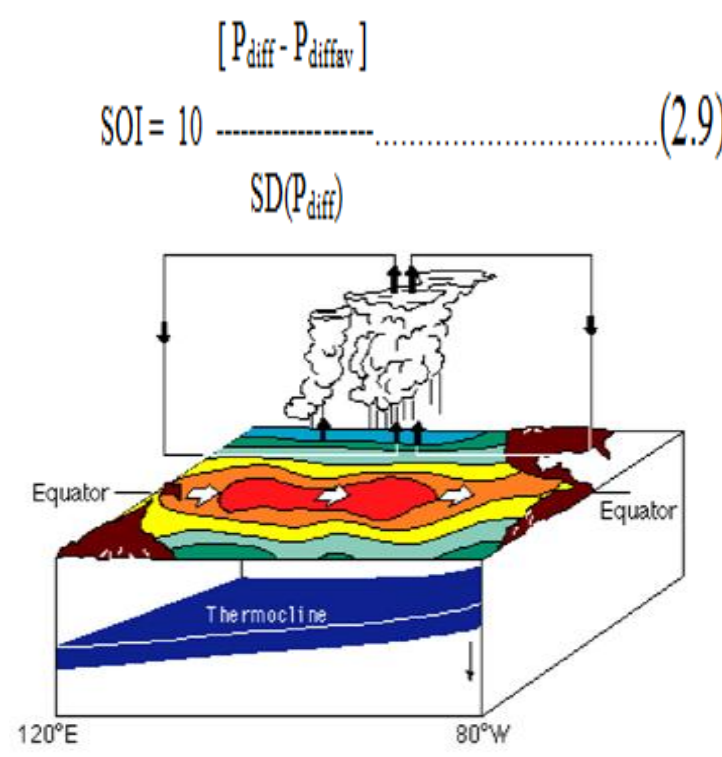

Gambar 2 Titik Pengukuran Indeks OsilasiSelatan ${ }^{[5]}$.

\subsection{SST}

Suhu muka laut (Sea surface Temperature SST) di perairan Indonesia sebagai indeks banyaknya uap air pembentuk awan di atmosfer (Kadarsah). Jika suhu muka laut dingin uap air di atmosfer menjadi berkurang, sebaliknya jika suhu muka laut panas uap air di atmosfer banyak. Pola suhu muka laut di Indonesia secara umum mengikuti gerak tahunan matahari. Suhu muka laut di Samudera Hindia mempunyai rentang perubahan yang cukup lebar yaitu minimum berkisar 26.0 $\mathrm{C}$ pada bulan Agustus hingga maksimum berkisar $31.5^{\circ} \mathrm{C}$ pada bulan Febrauari - Maret. Wilayah perairan lainnya umumnya mempunyai rentang perubahan lebih sempit yaitu berkisar $29.0^{\circ} \mathrm{C}$ hingga $31.5^{\circ} \mathrm{C}$ dan waktu terjadinya minimum dan maksimumnya tidak sama disetiap perairan.

\section{$2.6 I O D$}

Menurut sejarahnya IOD bukanlah suatu fenomena iklim yang baru. la sudah ada sejak sekitar tahun 1800-an. Namun, fenomena penyimpangan iklim ini baru pertama kali diungkap oleh Prof. Toshio Yamagata dari Tokyo University, Japan bersama rekannya dari India Dr. Saji N. Hameed dari Indian Institute of Science, Bangalore, India. Hal yang menarik dari fenomena ini adalah periodisitasnya yang berosilasi sekitar 15 bulanan yang pada waktuwaktu tertentu juga muncul antara selang waktu
3-4 tahun. Periodisitas ini penting diketahui agar dapat ditentukan sifat-sifat pengulangan akumulasi curab bujan pada periode tertentu. Proses pembentukan bujan di kawasan tropis, khususnya di Benua Maritim Indonesia (BMI) seperti yang kami jelaskan di atas merupakan salab satu proses yang paling sukar disimulasikan. Hingga saat ini belum ada satu model iklim pun yang mampu mensimulasikan curab bujan di Indonesia dengan baik. Korelasi pol a (pattern correlation) antara basil simulasi model dan basil observasi sebagian besar banya berkisar pada angka di bawab 0.5 (lihat Ratag M.A., 2002).

Indian Ocean Dipole (IOD) adalah laut digabungkan dan fenomena atmosfer di Samudra Hindia khatulistiwa yang mempengaruhi iklim Australia dan negaranegara lain yang mengelilingi cekungan Samudra Hindia (Saji et al 1999.). Besar variabilitas SST di Samudera Hindia telah dikaitkan dengan Indian Ocean Dipole (IOD), juga disebut sebagai Samudera Hindia zonal Mode (IOZM; Saji et al, 1999;. Webster et al, 1999.). Pola ini mewujud melalui gradien zonal SST tropis, yang pada satu tahap ekstrem di musim gugur boreal menunjukkan cooling off Sumatra dan pemanasan lepas pantai Somalia di sebelah barat, dikombinasikan dengan anomali timuran di sepanjang khatulistiwa. Besarnya curah hujan maksimum sekunder dari Oktober sampai Desember di Afrika Timur angat berkorelasi dengan kejadian IOD positif ${ }^{[21]}$. Menurut Sajiet al . (1999a $)^{[12]]}$ OODM adalah sebuah fenomena fisis samudera dan atmosfer di kawasan Samudera Hindia ekuator yang ditandai dengan adanaya anomali negatif suhu permukaan laut dibagaian barat Samudera Hindia. Sinyal fenomena IODM sering diasosiasikan dengan perubahan anomali suhu muka laut (SPL) antara Samudera Hindia tropis bagian Barat $\left(50^{\circ} \mathrm{E}-70^{\circ} \mathrm{E}\right.$ dan $\left.10^{\circ} \mathrm{S}-10^{\circ} \mathrm{N}\right)$ dengan Samudera Hindia tropis bagian Timur $\left(90^{\circ} \mathrm{E}-110^{\circ} \mathrm{E}\right.$ dan $10^{\circ} \mathrm{S}$ $10^{\circ}$ ekuator). Hasil penelitian ini memberikan nilai koefesien korelasi sebesar 0.7. Berdasarkan data reanalisis diketahui bahwa variabilitas antar musimam dan tahunan sirkulasi angin permukaan, suhu permukaan laut dan arus permukaan laut di wilayah perairan Samudera Hindia sangat dipengaruhi oleh sistem angin musim dan fenomena Indian Ocean Dipole. Perubahan pola angin, arus dan distribusi suhu permukaan laut terutama terjadi di belahan bumi bagian utara dan sebaliknya dibelahan bumi bagian selatan mempunyai pola yang lebih teratur dan relatif kecil perubahannya. Hal ini dimungkinkan karena di bagian utara Samudera Hindia dibatasi oleh Benua Asia sehingga pengaruh daratan sangat kuat, sedangkan di bagian selatan merupakan laut terbuka. Selain itu, ternyata IOD secara langsung maupun tidak langsung terkait erat dengan adanya Sirkulasi Walker (Walker Circulation) yang terjadi di sepanjang belt ekuator akibat adanya perbedaan tekanan antara wilayah bagian timur Samudera Hindia

Selain ENSO, Terjadi pula gejala penyimpangan iklim yang dihasilkan oleh interaksi laut dan atmosfer di Samudera Hindia di sekitar khatulistiwa yang disebut dengan IOD 
(Indian Ocean Dipole). Interaksi tersebut menghasilkan tekanan tinggi di Samudera Hindia bagian Timur (bagian Selatan Jawa dan Barat Sumatra) yang menimbulkan aliran massa udara yang berhembus ke Barat. Hembusan angin ini akan mendorong massa air di depannya danmengangkat massa air dari bawah ke permukaan. Akibatnya, SPL di sekitar pantai Selatan Jawa dan pantai Barat Sumatera akan mengalami penurunan yang cukup drastis, sementara di dekat pantai timur Afrika tejadi kenaikan suhu permukaan laut ${ }^{[9]}$.

Indian Ocean Dipole (IOD) adalah kondisi interaksi laut-atmosfer yang terjadi di samudera hindia tropis. Selama fenomena IOD positif (Gambar 3), suhu permukaan laut secara anomali menghangat di Samudera Hindia barat, sedangkan di bagian timur lebih dingin dari normalnya ${ }^{[11]}$. Perubahan pada suhu permukaan laut selama IOD terjadi terkait dengan perubahan medan angin di tengah samudera Hindia ekuator. Sehingga angin bergerak berlawanan dari biasanya barat ketimur selama IOD positif. Selain itu, proses konveksi yang biasanya terjadi di atas Samudera Hindia bagian timur yang menghangat bergerak ke arah barat. Hasil dari kondisi tersebut adalah hujan lebat di Afrika bagian timur dan meninggalkan wilayah Indonesia dengan sedikit hujan (e.g. Bahera et al. 2005, 2007), yang kemudian diikuti dengan kekeringan dan hutan yang terbakar. Fosil koral dari pantai Sumatera mencatat fenomena IOD beberapa kali di Holocene. Terkait dengan perubahan angin dan suhu permukaan laut dan menyerupai fenomena ENSO, kondisi IOD mempengaruhi konveksi di Indonesia dan curah hujan regionalnya (Yulihastin, E, dkk, 2009).
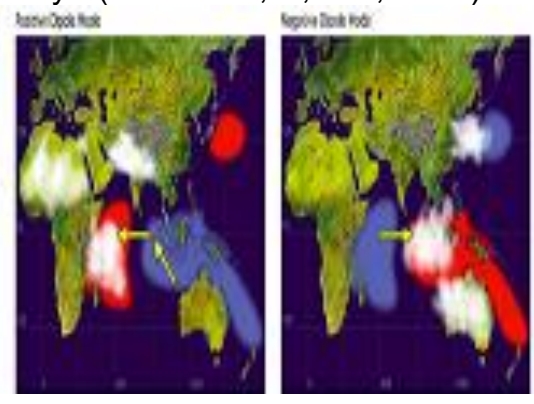

Gambar 3 Skema positif (kiri) dan negatif (kanan) IOD

\subsection{Cuaca}

IImu yang mempelajari tentang keadaan cuaca disebut meteorologi, adalah sebuah cabang ilmu pengtahuan yang mempelajari seluruh fenomena yang terjadi di atmosfer bumi. Pada lapisan ini terdapat penurunan suhu yang terjadi karena sangat sedikit troposfer menyerap radiasi gelombang pendek dari matahari, sebaliknya permukaan tanah memberikan panas pada lapisan troposfer yang terletak diatasnya (Roger, 1980). Sedangkan definisi cuaca itu sendiri adalah :

- Keadaan atmosfer secara keseluruhan pada suatu saat termasuk perubahan, perkembangan, dan menghilangnyasuatu fenomena di atmosfer bumi (world climate conference, 1979) (Roger, 1980).

- Keadaan variabel atmosfer secara keseluruhan di suatu tempat dalam selang waktu yang pendek ${ }^{[20]}$.

- Keadaan atmosfer yang dinyatakan dengan nilai berbagai parameter, antara lain suhu, tekanan angin, kelembaban, dan berbagai fenomena hujan, di suatu tempat atau wilayah tertentu selama kurun waktu yang pendek ${ }^{[9]}$.

Dari beberapa penjabaran definisi cuaca di atas,maka dapat disimpulkan bahwa cuaca adalah keadaan fisik atmosfer bumi pada suatu saat (waktu tertentu) di suatu tempat, dalam waktu singkat (pendek) berubah keadaannya, seperti panasnya, kelembabannya, atau gerak udaranya. Hubungan parameter fisis cuaca terhadap curah hujan yaitu

\subsection{Nilai Koefisien Korelasi}

Nilai koefisien korelasi berguna untuk mengetahui hubungan linier antara nilai curah hujan dengan nilai suhu, tekanan udara, kelembaban, kecepatan angin.Kelompok data sampel yang di maksud. Semakin tinggi nilai koefisien korelasi dengan nilai positif menunjukkan kuatnya hubungan linier dari masing-masing kelompok data sampel,

- Nilai koefisien korelasi sama dengan -1 menunjukkan berbanding terbalik, hubungan sangat kuat

- Nilai koefisien korelasi sama dengan 1 menunjukkan berbanding lurus, hubungan sangat kuat

- Nilai koefisien korelasi yang menunjukkan angka 0,5 - 1 , menujukkan kuatnya hubungan linier dan hubungannya kuat

- Nilai koefisien < 0,5 hubungan dari variabel data tidak cukup kuat atau tidak ada hubungan

Besarnya nilai koefisien korelasi dapat dihitung dengan menggunakan persamaan sebagai berikut:

Dimana :

$$
\mathrm{r}(\mathrm{x}, \mathrm{y})=\frac{\sum_{i=1}^{i=n} x i y i}{\sum_{i=1}^{i=n} x i^{2} \sum_{i=1}^{i=n} y i^{2}}
$$

$r(x, y)=$ nilai koefisien korelasi antara variabel

$x=$ nilai curah hujan rata -rata

$y=$ nilai suhu udara, tekanan udara, kelembaban udara dan kecepatan angin.

\subsection{Validasi}

Validitas adalah suatu ukuran yang menunjukkan tingkat kesahihan suatu tes. Suatu tes dikatakan valid apabila tes tersebut mengukur 
apa yang hendak diukur. Tes memiliki validitas yang tinggi jika hasilnya sesuai dengan kriteria, dalam arti memiliki kesejajaran antara tes dan kriteria $^{[2]}$.

\section{Metodologi}

\subsection{Data}

Data yang digunakan dalam kajianini adalah data curah hujan sebaran normal dari tahun 1981-2010 pada stasiun wilayah Pekanbaru-Provinsi Riau. Dalam simulasi model prakiraan curah hujan ini menggunakan input data SOI, SST, Nino 3.4, dan IOD. Data-data tersebut yang digunakan adalah nilai rata-ratanya untuk kondisi yang mewakili normalnya selanjutnya digunkan metode regresi linear berganda untuk memprediksi curah hujan $(\mathrm{CH})$ tahun 2011 dan 2012. Data jumlah curah hujan tahun 2011 dan 2012 hasil observasi dianggap sebagai pembanding untuk verifikasi dan validasi nilai curah hujan $(\mathrm{CH})$ hasil model output simulasi.

Adapun alamat data input diambil dari

1. SOI

http://www.bom.gov.au/climate/current/soihtm1. shtml

2. SST

BMKG Stasiun Pekanbaru-Riau

3. Nino 3.4

http://www.esrl.noaa.gov/psd/gcos_wgsp/Times eries/Nino34/

4. IOD :

http://www.jamstec.go.jp/frcgc/research/d1/iod/ HTML/ Dipole\%20Mode\%20Index.html

\subsection{Metode}

Pada kajian penelitian ini digunakan metode yaitu metode regresi linear berganda dan koefisien korelasi.Metode prediksi regresi linier berganda ini dilakukan dengancara membentuk persamaan regresi yang digunakan untuk melakukan simulasi prediksi jumlah curah hujan bulanan menggunakan lebih dari dari satuvariabel independen. Kemudian hasil prediksi jumlah curah hujan bulanan menggunakaninput data parameter cuaca yaitu suhu udara, tekanan udara, kelembaban udara, jumlah hari hujan dan kecepatan

angininidibandingkandengandataobservasi.Adapu

$\mathrm{n}$ persamaan umummetode ini adalah sebagai berikut

$\mathrm{Y}=\mathrm{B}_{0}+\mathrm{B}_{1} \mathrm{X}_{1}+\mathrm{B}_{2} \mathrm{X}_{2}+\ldots . .+\mathrm{B}_{\mathrm{k}} \mathrm{XK}^{[5]}$

Dengan: $\mathrm{B}_{\mathrm{O}}=$ konstanta; $\mathrm{B}_{1}, \mathrm{~B}_{2}, \ldots . . \mathrm{B}_{\mathrm{k}}=$ koefisienvariabel $\mathrm{X}_{1}, \mathrm{X}_{2}, \ldots, \mathrm{X}_{\mathrm{k}} ; \mathrm{Y}=$ variabel yang

diduga (variabel dependen); dan $\mathrm{Xi}=$ variabelpenduga(variabelindependen).

Untuk analisisdengan metode regresi dibedakan dua jenis variabel ialah variabel bebas(independent)atauvariabelprediktordan variabel tidak bebas (dependent) atau variabel respon. Variabelbebasmerupakanvariabel yang dapat mempengaruhi varibel tidak bebas atau variabel yang dapat memprediksi harga variabeltidakbebas. Variabelinidinyatakan dengan $\mathrm{X}_{1}, \mathrm{X}_{2}, \ldots, \mathrm{X}_{\mathrm{k}}$.Sedangkanvariabeltidak

bebasmerupakanvariabelyangterjadikarena

variabel bebas atau variabel yang mencerminkan respondarivariabel bebas, dinyatakandengan $\mathrm{Y}^{[8]}$.

Dalam kajian ini memiliki 3 variabel bebas atau variabel penduga yaitu curah hujan bulanan, jumlah hari hujan, dan kelembaban udara, dimana dalam persamaan regresi linear berganda untuk model prediksi yang valid sebaiknya digunakan lebih banyak variabel bebas,sedangkanvariabeltidak

bebas(dependent)atauvariabelresponadalahjumla h curah hujan bulanan. Penulis untuk mengecek kebenaran dan validasi dari nilai suhu udara hasil model dengan nilai suhu udara rata-rata sebenarnya hasil observasi dilakukanlah langkah uji koefisien korelasi dari kedua sambel data yang diuji. Rumusan Korelasi :

$r(X, Y)=\frac{n \cdot \Sigma x y-\Sigma x \cdot \Sigma y}{\operatorname{Sqr}\left\{\left(n \cdot \Sigma x^{2}-(\Sigma x)^{2}\right)\left(n . \Sigma y^{2}-(\Sigma y)^{2}\right)\right\}}$

Nilai $r$ adalah nilai yang menyatakan kuat tidaknya hubungan antara nilai $x$ dan nilai $y$, nilai $r$ ini berada diantara - 1 sampai dengan 1 atau dapat dinyatakan sebagai berikut:

$$
-1 \leq r(x, y) \leq 1
$$

artinya:

1. $r(x, y)=+1$, hubungan antara $x$ dan $y$ sempurna dan positif (mendekati +1 ), berarti hubungan keduanya sangat kuat dan bersamaan fase atau berbanding lurus.

2. $r(x, y)=-1$, hubungan antara $x$ dan $y$ sempurna dan negatif (mendekati -1), berarti hubungan sangat kuat dan berlawanan fase atau berbanding terbalik.

3. Apabila nilai $r(x, y) \geq+0,5$ atau $r(x, y) \leq-0,5$, berarti hubungan antara $x$ dan $y$ dianggap cukup kuat.

4. Apabila nilai $r(x, y)<+0,5$ atau nilai $r(x, y)$ $>$ - 0,5 berarti hubungan antara $x$ dan $y$ dianggap lemah.

Verifikasi data digunakan untuk mencari tingkat kebenaran apakah data yang dihasilkan radar dan satelit sesuai kebenaran atau tidak (aktual). Adapun rumus yang digunakan untuk perhitungan statistik adalah MAE, MAPE dan RMSE.MAEmerupakan hasil nilai mutlak dari selisih antara nilai keluaran model dengan data sebenarnya. Rumus MAE adalah sebagai berikut (Stephens.J.larry,danSpiegel.R murray 2007)

RMSE merupakan akar kuadrat rata-rata dari selisih antara output model dengan data yang sebenarnya. Rumus MSE adalah sebagai berikut: 
RMSE $=\sqrt{\frac{\sum\left(n_{f}-n_{a}\right)^{2}}{m}}$

Untuk menguji validasi kebenaran model yang di hasilkan

1. Metode grafik

2. Metode validasi menggunakan RMSE

3. Metode Korelasi

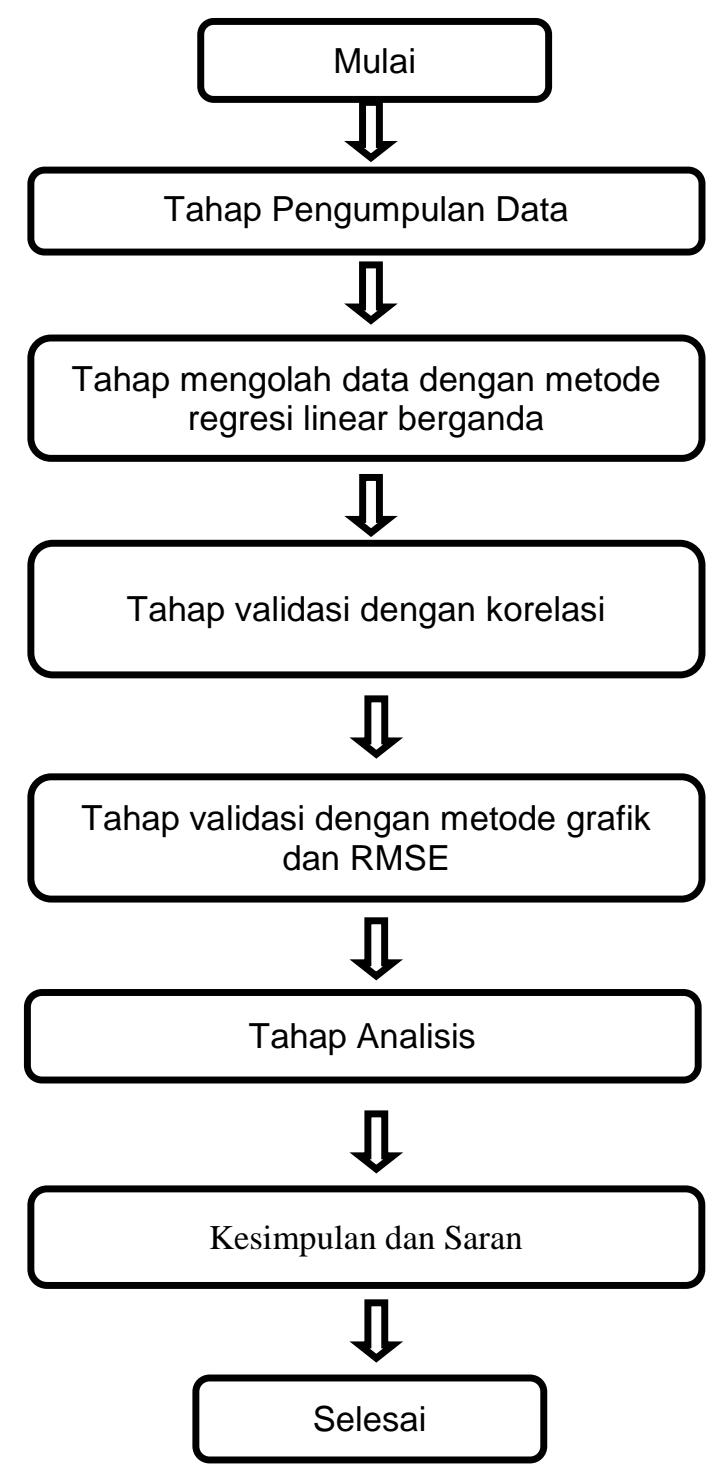

Gambar 4 Diagram alir pengolahan Data

\section{HASIL DAN PEMBAHASAN}

Dari hasil penelitian yang telah dilakukan dengan mengunakan regresi linear berganda dan koefisien korelasi didapatlah rumus persamaan curah hujan pada tahun 2011 dan 2012 untuk wilayah Pekanbaru sebagai berikut terlihat pada tabel 1. Model Persamaan regresi linear berganda curah hujan dengan predictor SOI, SST, NINO 3.4, DIO.

Dari tabel 1 dapat diketahui persamaan untuk menentukan prakiraan curah hujan dengan menggunakaninput data SOI, SST, Nino 3.4, dan IODdidapatkan model seperti berikut :

$$
Y=-420,421+3,542 X_{1}+23,125 X_{2}-15,014 X_{3}
$$

Setelah didapatkan persamaan diatas dimasukkan nilai data SOI, SST, Nino 3.4, dan IOD untuk memprediksi curah hujan pada tahun 2011 dan 2012.

\begin{tabular}{lr}
\multicolumn{2}{c}{ Tabel 2 Hasil RSME } \\
\hline RSME CH 2011 & 190.6948691 \\
\hline RSME CH 2012 & 53.76240031 \\
\hline
\end{tabular}

Berdasarkan table 2 diatas menjelaskan hasil dari RMSE yang mempengaruhi pola curah hujan, terlihat dari table tersebut untuk tahun 2011 memiliki nilai RMSE sebesar 190,69 sedangkan untuk RMSE pada tahun 2012 memiliki nilai sebesar 53,76. Dari perbedaan hasil data tersebut meunjukkan bahwa tingkat kesalahan untuk tahun 2012 lebih besar dibandingkan tahun 2011.

\begin{tabular}{|c|c|c|}
\hline No & Model & Hasil \\
\hline 1 & SOI & 0.300663 \\
\hline 2 & Nino 3.4 & -0.213932 \\
\hline 3 & SST & 0.062097 \\
\hline 4 & IOD & -0.175278 \\
\hline
\end{tabular}

Pada table diatas menunjukkan hasil validasi model curah hujan berdasarkan data predictor SOI, SST, Nino 3.4, dan IOD. SOI dengan $\mathrm{CH}$ memiliki hubungan sebanding dengan nilai sebesar $30 \%$.Sedangkann predictor Nino 3.4 memiliki hubungan berbanding terbalik dengan curah hujan yang memiliki nilai sebesar $21 \%$.Kemudian untuk predictor SST memiliki hubungan sebanding dengan curah hujan yang memiliki nilai sebesar 6\%.dan IOD memiliki hubungan berbanding terbalik dengan curah hujan sebesar $17 \%$.

Dari hasil table tersebut terlihat bahwa yang paling berpengaruh atau memiliki hubungan korelasi yang tinggi pada pola curah hujan di wilayah Pekanbaru untuk tahun 20122 dan 2012 adalah predictor SST dan SOI. Namun karena hasil dari SST hanya $6 \%$ maka tidak terlalu berpengaruh terhadap curah hujan diwilayah Pekanbaru dibandingkan dengan SOI, selain itu data SST diambil dari bagian barat sebelah Sumatra. Total dari hasil data yang dihasilkan predictor SOI, SST, Nino 3.4, dan IOD memiliki nilai sebesar $74 \%$ sehingga sisanya dikurangi dari total keseluruhan yaitu $100 \%-74 \%$ didapatlah nilai lokalnya untuk wilayah Pekanbaru sebesar $26 \%$. 
dengan prediktor SOI, SST, Nino 3.4, DIO

\begin{tabular}{|c|c|c|c|c|c|c|c|c|}
\hline & Coefficients & $\begin{array}{l}\text { Standard } \\
\text { Error }\end{array}$ & t Stat & $P$-value & Lower 95\% & Upper 95\% & Lower $95.0 \%$ & Upper $95.0 \%$ \\
\hline Intercept & 420.4212599 & 808.5233438 & 0.519986545 & 0.607647232 & 2085.606257 & 1244.763738 & 2085.606257 & 1244.763738 \\
\hline X Variable 1 & 3.54230702 & 2.720360101 & 1.302146366 & 0.204736284 & 2.060379484 & 9.144993525 & 2.060379484 & 9.144993525 \\
\hline X Variable 2 & 23.12526637 & 29.88702701 & 0.773755997 & 0.446330708 & 38.42821798 & 84.67875072 & 38.42821798 & 84.67875072 \\
\hline$X$ Variable 3 & 0.902133588 & 1.580518602 & 0.570783277 & 0.573241924 & 2.353005407 & 4.157272582 & 2.353005407 & 4.157272582 \\
\hline$X$ Variable 4 & 15.01497646 & 35.09256922 & $\begin{array}{c}- \\
0.427867688\end{array}$ & 0.672410809 & 87.28947568 & 57.25952276 & 87.28947568 & 57.25952276 \\
\hline
\end{tabular}

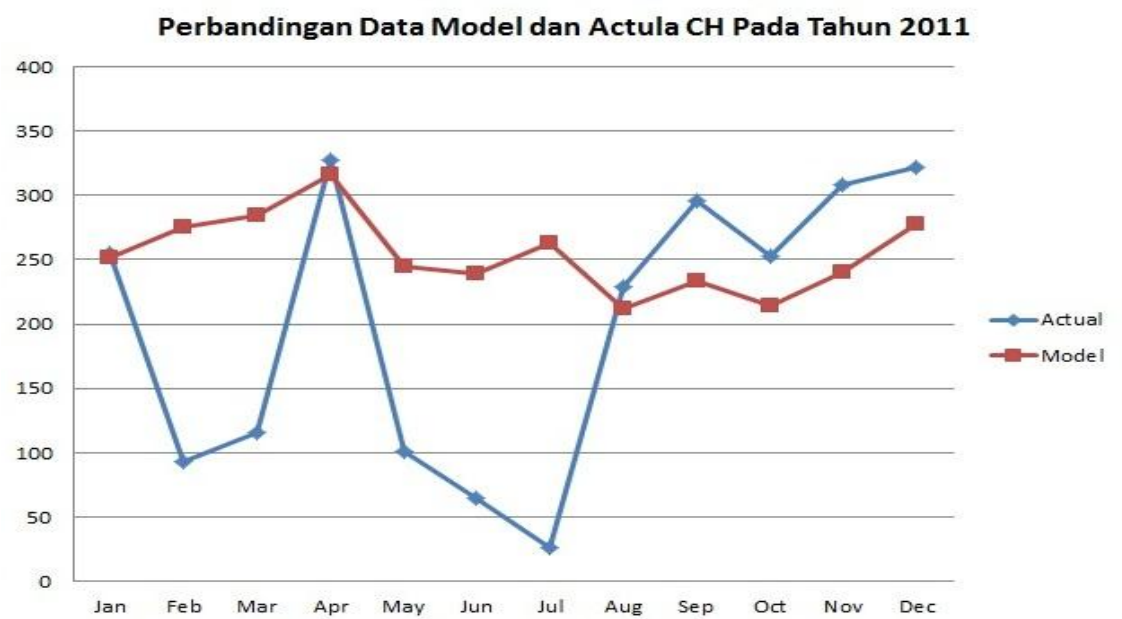

Gambar 5 Perbandingandata model dan actual $\mathrm{CH}$ pada tahun 2011

Gambar diatas menjelaskan hubungan korelasi antar curah hujan pada tahun 2011 dengan data SOI, SST, Nino 3.4, dan IOD, Dari gambar tersebut menunjukkan adaya korelasi antara data model dengan data predictor yag mendekati model actual yaitu pada bulan Januari, April, Agustus, September, Oktober, November dan Desember.

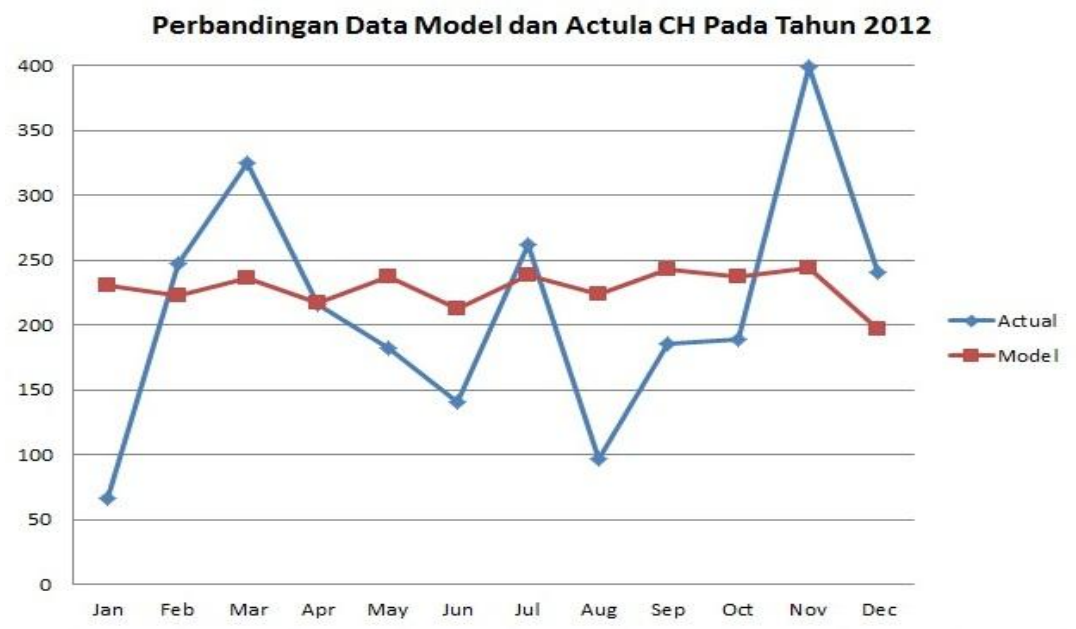

Gambar 5 Perbandingandata model dan actual $\mathrm{CH}$ pada tahun 2012

Gambar diatas menjelaskan hubungan korelasi antar curah hujan pada tahun 2011 dengan data SOI, SST, Nino 3.4. Dari gambar tersebut menunjukkan adaya korelasi antara 
data model dengan data data predictor yang mendekati model actual yaitu pada bulan Februari, April, Juli dan Desember.

\section{KESIMPULAN}

Berdasarkan penelitian yang telah dilakukan maka dapat disimpulkan bahwa data dari SOI, SST, Nino 3.4 dan IOD memiliki pengaruh terhadap curah hujan di wilayah Pekanbaru Provinsi Riau. Dari hasil penelitian terlihat hubungan yang memiliki tingkat korelasi yang tinggi terhadap curah hujan $(\mathrm{CH})$ adalah data SOI dan SST. Selain factor global dan regional, factor lokal juga mempengaruhi curah hujan di wilayah pekanbaru.

\section{DAFTAR PUSTAKA}

Anshari, M K., S. Arifin, A. Rahmadiansah. 2013. Perancangan Prediktor Cuaca Maritim Berbasis Logika Fuzzy Menggunakan User Interface.Android. Jurnal Teknik POMITS Vol. 2, No. 2, (2013) ISSN: 2337-3539 (2301-9271 Print

Arikunto, Suharsimi. 1999. Prosedur Penelitian: Suatu Pendekatan Praktek.ed. Rev. IV. Yogyakarta: Rineka Cipta.

Asdak, C., 2002. Hidrologi dan Pengelolaan Daerah Aliran Sungai. Gajah Mada University Press. Yogyakarta.

BMG. 2006. Perakiraan Musim Hujan 2006/2007 BMG. Jakarta.

BMKG. 2009.Titik Pengukuran ONI. BMKG: Jakarta

Boer R. 2002. Fenomena ENSO dan Hubungannya Dengan Keragaman Hujan di Indonesia dalam Pelatihan Dosen PT Se-Sumatera-Kalimantan dalm Bidang Pemodelan dan Simulasi Pertanian dan Lingkungan, Bogor, 1-13 Juli 2002.

Choir, Unmul, Zakir andAchmad.Kajian Indeks StabilitasUdara Model KMA di Wilayah Indonesia Bulan April dan Mei2007.s.I.: Laporan BMG,2007

Critchfield, H.J. 1979. General Climatology. Prentice Hall of India, Private Limited, New Delhi. 446 hal.

Gibbs, J. W. 1987. Definiting Climate. WMO Buletin No. 4, Vol. 36, Oct 1987

Kailaku, T.E, (2009). Pengaruh ENSO (El NinoSouthern Oscillation) DAN IOD (Indian Ocean Dipole) Terhadap Dinamika Waktu Tanam Padi di Wilayah Tipe Hujan Equatorial dan Monsunal (Studi Kasus Kabupaten Pesisir Selatan, Sumatera Barat dan Kabupaten Karawang, Jawa Barat). Skripsi. Jurusan Meteorologi FMIPA IPB. Bogor
Nugroho, S. 2003. Kaitan El-Nino 1997 Terhadap Tingkat Kekeringan dan Musim di Sumatera Barat, Jurnal Meteorologi dan Geofisika, Vol. 4 No. 2 April - Juni 2003, BMG Jakarta.

Saji, N. H., Goswami, B. N., Vinayachandran, P. N., and Yamagata, T. (1999). A dipole mode in the tropical Indian Ocean. Nature, 401, 360-363.

Shelton, M. L., 2009, Hydroclimatology : Perspectives and Applications, New York : Cambridge University Press.

Sucahyono, D. dan Fatchiyah. 2005. Variabelitas hujan di Sulawesi dan korelasinya dengan anomali suhu muka laut di samudera hindia bagian tenggara dan ENSO periode 2001 - 2005. Jur. Met. Geo., Vol. 6, No.2, Juni 2005, hal. : 87 97. BMG Jakarta.

Sulistya, W.,1998. Pengaruh El-Nino 1997/1998 di Wilayah Indonesia, Bulletin Meteorologi Geofisika, No. 4 Desember 1998, halaman 44-55. BMG Jakarta.

Supranto, J. 2008. Statistik Teori dan Aplikasinya. Erlangga. Jakarta.

Tjasyono, B.H.K. 2002. Meteorologi Indonesia 2. Jakarta; Badan Meteorologi dan Geofisika.

Tjasyono,B.HK. 2006. Ilmu Kebumian dan Antariksa. Bandung: PT. Remaja Rosdakarya bekerjasama dengan Program Pascasarjana UPI

Tjasyono, B.H.K., 2004. Klimatologi, ITB, Bandung. Thewartha , R. (1980). Global Climate. Journal ( page : 3 ). New York

Xie Z, Pang YS, Liu J, Deng X, Tang X, Sun J, Khan MI. 2006. A Multiplex RT-PCR for Detection of Type A Influenza Virus and Differentiation of Avian $\mathrm{H} 5, \mathrm{H} 7$, and $\mathrm{H} 9$ Hemaglutinin Subtypes. Mol Cell Probes 20:245-249. 